\title{
PENGAWETAN DAGING SEGAR DENGAN EKSTRAK METABOLIK BAKTERI ASAM LAKTAT DARI BUAH TOMAT
}

\author{
Suwedo Hadiwiyoto ${ }^{1}$, Endang Sutriswati Rahayu ${ }^{1}$, dan Irawan Yudha Bawono ${ }^{2}$
}

\begin{abstract}
INTISARI
Penelitian ini bertujuan mempelajari kemampuan ekstrak metabolik yang dihasilkan oleh bakteri asam laktat untuk mempertahankan kesegaran daging. Bakteri asam laktat diisolasi dari buah tomat masak pohon dengan menggunakan media selektif MRS agar menurut prosedur standar untuk isolasi dan identifikasi bakteri. Penyimpanan daging dilakukan pada suhu $5^{\circ} \mathrm{C}$ di dalam refrigerator. Ekstrak metabolik diproduksi dengan menumbuhkan bakteri asam laktat hasil isolasi pada MRS broth dan jus tomat pada suhu kamar selama 48 jam dengan menggunakan electric shaker. Hasil isolasi dan identifikasi menunjukkan adanya tiga isolat, kesemuanya adalah Streptococcus lactis yang diberi kode masing-masing A, B, dan C. Streptococcus lactis A mampu menghasilkan ekstrak metabolik dengan daya penghambatan terhadap bakteri psikrofil daging paling besar. Pada MRS broth, Streptococcus lactis A menghasilkan ekstrak metabolik EMM yang keasamannya 1,55\%, kandungan hidrogen peroksida $0,75 \%$ dan mempunyai nilai $\mathrm{pH} 5,62$, sedangkan pada jus tomat dihasilkan ekstrak metabolik EMT dengan kandungan asam 2,14\%, hidrogen peroksida $0,91 \%$ dan nilai $\mathrm{pH} 4,74$. Pencelupan daging sapi selama 1 menit dalam EMM atau EMT menunjukkan adanya penghambatan terhadap laju peningkatan TVB, nilai $\mathrm{pH}$, dan populasi bakteri selama penyimpanan delapan hari dibandingkan dengan kontrol daging yang dicelup dalam aquades steril atau larutan asam sitrat $\mathrm{pH} 4,93$. Kadar TVB, nilai $\mathrm{pH}$ dan populasi bakteri selama penyimpanan daging yang dicelup dalam EMT lebih rendah daripada yang dicelup dalam EMM. Daging kontrol telah mengalami pembusukan pada hari kelima penyimpanan, sementara daging yang dicelup dalam EMM maupun dalam EMT sebelum penyimpanan belum menunjukkan adanya pembusukan sampai hari kedelapan penyimpanan.
\end{abstract}

(Kata kunci : Bakteri asam laktat, Pengawetan daging, Ekstrak metabolik).

Buletin Peternakan 29 (1): 35 - 43, 2005

\footnotetext{
${ }^{7}$ Fakultas Teknologi Pertanian UGM Yogyakarta.

'Alumni Fakultas Teknologi Pertanian UGM.
} 


\title{
PRESERVATION OF FRESH MEAT USING METABOLIC EXTRACT PRODUCED BY LACTIC ACID BACTERIA ISOLATED FROM TOMATO FRUIT
}

\begin{abstract}
The research was objected to study the ability of metabolic extract produced by lactic acid bacteria for prolonging shelf life of fresh meat. Lactic acid bacteria was isolated from riped tomato fruit using selective media MRS agar by standard prosedure for isolation and identification of bacteria. Fresh meat was stored in refrigerator at $5^{\circ} \mathrm{C}$. Metabolic extract was produced by planting isolated lactic acid bacteria in MRS broth and tomato juice at room temperature for 48 hours in electric shaker. The result of isolation and identification showed three isolates, all were Streptococcus lactis coded by A, B, and C respectively. S. lactis was able to produce metabolic extract with greatest inhibition power to psychrophyl meat bacteria compared than those of other isolates. In MRS broth this bacteria produced metabolic extract EMM with acid concentration of $1.55 \%$, hydrogen peroxide of $0.75 \%$, and $\mathrm{pH} 5.62$, while in tomato juice it could produce metabolic extract EMT with acid concentration of $2.14 \%$, hydrogen peroxide of $0.91 \%$, and $\mathrm{pH}$ 4.74. Deeping of fresh meat for one mimute in EMM or in EMT could inhibit the rate of increasing of TVB, $\mathrm{pH}$ value, and bacteria population during eight days storage compared than those of controls, i.e. meat deeped in steril aquadest or in citric acid solution of $\mathrm{pH}$ 4.93. The TVB, $\mathrm{pH}$ value, and bacteria population during storage of meat deeped in EMT was lower than those of meat deeped in EMM. Meat controls had been spoiled at the day five of storage while meat deep in EMM or in EMT before storage did not spoil until eight days of storage.
\end{abstract}

(Key words : Lactic acid bacteria, Fresh meat preservation, Metabolic extract).

\section{Pendahuluan}

Daging dalam keadaan segar mudah mengalami kerusakan sebagai akibat adanya reaksi-reaksi kimiawi, enzimatik, dan aktivitas mikrobia terutama bakteri yang berlangsung secara bersamaan. Pada umumnya kerusakan oleh bakteri mendominasi peristiwa-peristiwa kerusakan lainnya. Cara yang sudah umum dilakukan untuk mempertahankan kesegaran daging adalah dengan pendinginan dan pembekuan. Meskipun demikian berbagai cara lain telah ditempuh untuk tujuan yang sama, yang dalam aplikasinya dikombinasikan atau tanpa dikombinasikan dengan pendinginan. Diharapkan masa simpan daging segar menjadi lebih lama lagi daripada hanya dengan didinginkan saja. Widayaka dan Hendratmo (1991) melakukan percobaan pengawetan daging dengan menggunakan campuran garam $10 \%$ dan glukosa $20 \%$ kemudian melakukan penyimpanan pada suhu $4^{\circ} \mathrm{C}$, dengan hasil mula-mula memang dapat menekan kerusakan daging tetapi sampai hari ketujuh kesegaran daging tidak berbeda lagi dengan kontrol. Usaha mempertahankan kesegaran selama penyimpanan dingin juga telah dilakukan oleh Ahmad and Marcello (1989) dengan menggunakan metode atmosfer terkendali dengan komposisi karbondioksida, oksigen, dan nitrogen yang berbeda-beda. Meski pun demikian sampai hari ke 12 pada suhu $4^{\circ} \mathrm{C}$ jumlah bakteri anaerobik terus meningkat, bahkan juga terdapat bakteri patogen. Sudiarti (1978) mengkombinasikan perlakuan pasteurisasi daging pada suhu $65^{\circ} \mathrm{C}$ selama 30 menit dengan penggunaan antibiotika (tetrasiklin $7 \mathrm{ppm}$ ) untuk pengawetan daging, hasilnya daging masih dapat diterima konsumen sampai penyimpanan berlangsung 8 hari pada suhu $5^{\circ} \mathrm{C}$. Meskipun demikian penggunaan antibotika banyak dihindari oleh karena akan dapat meninggalkan residu. Pada tahun 1970-an sudah banyak peneliti yang menggunakan bakteri asam laktat untuk memberikan citarasa dan warna menarik pada daging. Reddy et al. (1970) menggunakan Lactobacillus citrovorum dan Streptococcus lactis untuk menghambat pertumbuhan bakteri gram negatif dan memberikan citarasa dan warna lebih menarik pada daging giling yang disimpan pada suhu 
$7^{\circ} \mathrm{C}$. Reddy and Chen (1975) menggunakan bakteri yang sama ditambah dengan asam askorbat untuk mempertahankan kesegaran daging selama penyimpanan pada suhu $7^{\circ} \mathrm{C}$. Meski pun demikian sejauh ini masih sangat jarang penelitian yang menggunakan ekstrak metabolik yang dihasilkan oleh bakteri asam laktat untuk tujuan mempertahankan kesegaran maupun untuk pengawetan daging. Penelitian ini bertujuan mengisolasi bakeri asam laktat dari alam (buah tomat) kemudian mempelajari kemampuannya menghasilkan ekstrak metabolik untuk mempertahankan kesegaran daging.

\section{Materi dan Metode}

\section{Bahan}

Daging sapi segar bagian lulur luar didapatkan dari rumah potong hewan (RPH) di kota Yogyakarta. Bagian lemak yang melekat pada daging dihilangkan dengan penyayatan. Daging dari RPH langsung digunakan untuk percobaan tanpa disimpan atau diberikan perlakuan lain selain penghilangan lemak. Buah tomat yang telah masak pohon warna merah. Media MRS broth dan MRS agar dari Oxoid sedangkan bahan-bahan kimia dari BDH, Merck, dan Sigma Chemical Co. Bakteri asam laktat diperoleh dengan cara isolasi dari buah tomat.

\section{Preparasi ekstrak metabolik}

Isolasi bakteri asam laktat dari buah tomat menggunakan media MRS agar dengan metoda streak plate. Pemilihan isolat bakteri asam laktat dilakukan dengan menguji daya penghambatan ekstrak metabolik yang dihasilkan dari MRS broth dan dari jus buah tomat pada suhu $37^{\circ} \mathrm{C}$ selama 48 jam. Pengujian daya penghambatan ekstrak metabolik terhadap bakteri daging dilakukan dengan metoda seperti yang dikemukakan oleh Pulusani et al. (1979). Kertas saring. Whatman No, $1(\varnothing 12 \mathrm{~mm})$ steril dicelupkan ke dalam ekstrak metabolik secara aseptik, kemudian diletakkan pada media MRS agar yang telah ditaburi dengan bakteri daging (berasal dari $10 \mathrm{~g}$ daging disuspensikan dalam $90 \mathrm{ml}$ aquades steril kemudian ditaburkan pada
MRS agar dengan metode pour plate), lalu diinkubasikan pada suhu $5^{\circ} \mathrm{C}$ selama 5 hari. Daya penghambatan ekstrak metabolik dinyatakan sebagai luasan zona jernih yang terbentuk di sekeliling kertas saring. Makin luas zona jernih yang terbentuk makin besar daya penghambatan ekstrak. Isolat dengan daya penghambatan ekstrak metabolik tertinggi selanjutnya diuji dengan pengecatan gram, uji katalase, dan pengecatan spora menurut Jutono et al. (1980), pengujian sifat homo-/heterofermentatif, pengamatan bentuk dan susunan sel, pengujian fisiologis (pertumbuhan pada suhu dan $\mathrm{pH}$ tertentu) menurut Beishir (1974) untuk keperluan identifikasi genus dan spesiesnya. Isolat trerpilih ditumbuhkan pada media MRS agar miring untuk keperluan stok selama percobaan.

Bakteri asam laktat dari stok MRS agar ditumbuhkan pada MRS broth ( 1 ose dalam $10 \mathrm{ml}$ media) pada suhu kamar selama 48 jam. Sentrifugasi pada $6000 \mathrm{xg}$ selama 15 menit dilakukan untuk memperoleh sel bakteri asam laktat dengan membuang supernatannya. Sel kemudian dicuci dengan aquades steril dan disentrifugasi lagi dengan cara yang sama. Sel yang diperoleh disuspensikan ke dalam larutan $1 \%$ tripton dan merupakan suspensi bakteri asam laktat yang akan dipergunakan untuk memproduksi ekstrak metabolik.

Lima $\mathrm{ml}$ suspensi bakteri ditambahkan masing-masing ke dalam $495 \mathrm{ml}$ MRS broth dan jus buah tomat steril, kemudian diinkubasikan pada suhu kamar selama 48 jam dengan terus dilakukan penggoyangan dengan menggunakan electric shaker. Ekstrak metabolik dari MRS broth diperoleh dengan melakukan sentrifugasi pada kecepatan $4000 \mathrm{xg}$ selama 15 menit dan mengumpulkan supernatannya, sedangkan ekstrak metabolik jus buah tomat diperoleh dengan penyaringan menggunakan kertas Whatman No. 41 dan mengumpulkan filtratnya. Baik supernatan mau pun filtrat kemudian disaring dengan menggunakan membrane millipore (Sortorius, ø pori $0,4 \mu \mathrm{m}$ ) untuk m e mbebaskan ekstrak dari keberadaan bakteri. Filtrat steril digunakan untuk mengawetkan daging. 


\section{Pengawetan daging}

Untuk percobaan pengawetan daging digunakan $25 \mathrm{~g}$ daging segar. Daging dicelupkan dalam ekstrak metabolik tanpa pengenceran selama satu menit pada suhu kamar. Setelah diangkat dan ditiriskan, daging disimpan dalam refrigerator pada suhu $5^{\circ} \mathrm{C}$ dengan $\mathrm{RH} 84 \%$ selama 8 hari. Dikerjakan juga pencelupan daging segar ke dalam aquades steril dan ke dalam larutan asam sitrat steril ( $\mathrm{pHnya}$ sama dengan $\mathrm{pH}$ ekstrak metabolik dari jus buah tomat) dengan cara yang sama sebagai kontrol.

\section{Analisis kimiawi dan mikrobiawi}

Selama penyimpanan dilakukan pengamatan kimiawi dan mikrobiawi. Nilai $\mathrm{pH}$ diukur menurut metode Reddy et al. (1970). Daging ( $15 g$ ) diblender bersama-sama dengan $50 \mathrm{ml}$ aquades, kemudian disaring dengan kertas Whatman No. 1 untuk memperoleh filtrat. Pengukuran $\mathrm{pH}$ dilakukan pada filtrat dengan menggunakan pHmeter.

Perubahan kandungan basa volatil (TVB) ditera dengan metode Conway seperti yang dikemukakan Darmadji (1990). Daging (10g) dihomogenisasi dengan $90 \mathrm{ml}$ aquades, kemudian ditambahkan $10 \mathrm{ml}$ larutan $20 \%$ TCA dan didiamkan selama 10 menit. Satu mililiter filtrat hasil penyaringan homogenat dengan kertas Whatman No. 1 ditempatkan pada bagian luar cawan Conway. Larutan kalium karbonat jenuh dan reagen asam borat $(10 \mathrm{~g}$ dalam $200 \mathrm{ml}$ alkohol) masing-masing dalam jumlah yang sama dengan sampel, ditempatkan masingmasing di bagian luar terpisah dengan sampel dan ditengah cawan Conway. Indikator $(0,0066 \%$ metil merah dan $0,033 \%$ metil biru dalam $100 \mathrm{ml}$ alkohol) ditambahkan ke dalam sumuran cawan. Kemudian cawan ditutup dan diinkubasikan pada suhu $37^{\circ} \mathrm{C}$ selama 80 menit. Setelah inkubasi, reagen asam borat dalam sumuran cawan dititrasi dengan larutan asam sulfat $0,02 \mathrm{~N}$ sampai warnanya berubah dari hijau menjadi ungu. Besarnya basa volatil dinyatakan sebagai miligram nitrogen per $100 \mathrm{~g}$ daging.

Uji Eber (Kurniasih et al., 1989) untuk mengetahui pembusukan pada daging dilakukan dengan meletakkan daging di atas $5 \mathrm{ml}$ reagen
Eber $(\mathrm{HCl}$ pekat + alkohol $96 \%$ dengan rasio 1:3) dalam tabung reaksi (ø 2,5 $\mathrm{cm}$ ). Tabung reaksi ditutup rapat. Jika terdapat kabut berwarna putih menandakan daging telah membusuk.

Populasi bakteri asam laktat selama penyimpanan daging segar dievaluasi dengan metode plate count dan dinyatakan dalam colony forming unit (CFU) per gram sampel.

\section{Hasil dan Pembahasan}

Isolasi bakteri asam laktat dari buah tomat mendapatkan tiga isolat yang setelah diuji menunjukkan tanda-tanda seperti yang disebutkan oleh Buchanan and Gibbons (1974) dan Sneath et al. (1982), sehingga ketiganya kemungkinan besar adalah Streptococcus lactis (Tabel 1 dan Tabel 2). Disebutkan oleh Buchanan and Gibbons (1974) dan Sneath et al. (1986) bahwa S. lactis dapat tumbuh dengan baik pada suhu $10^{\circ} \mathrm{C}$ dan $40^{\circ} \mathrm{C}$ tetapi tidak dapat tumbuh pada suhu $45^{\circ} \mathrm{C}$. Bakteri tersebut juga tumbuh baik pada media MRS broth yang mengandung $4 \% \mathrm{NaCl}$ dan pada susu yang ditambah $0,3 \%$ metil biru. Dalam media MRS broth yang mengandung $\mathrm{NaCl} 6,5 \%$ atau MRS broth $\mathrm{pH} 9,6, S$. lactis tidak dapat tumbuh.

Ketiga isolat mampu memproduksi ekstrak metabolik pada media MRS broth dan dari jus buah tomat yang mempunyai daya penghambatan terhadap pertumbuhan bakteri psikrofil dari daging segar. Meski pun demikian ekstrak metabolik yang dihasilkan oleh isolat A mempunyai daya penghambatan paling besar, diikuti oleh isolat B dan isolat C. Sifat kimiawi ekstrak metabolik isolat A dan media pertumbuhannya dicantumkan pada Tabel 3 . Esktrak metabolik bakteri asam laktat dari jus buah tomat (selanjutnya akan disebut EMT) mempunyai nilai $\mathrm{pH}$ lebih rendah dan kandungan $\mathrm{H}_{2} \mathrm{O}_{2}$ lebih tinggi daripada ekstrak metabolik dari MRS broth (selanjutnya akan disebut EMM). Hal ini disebabkan oleh karena bahan dasar EMT, yaitu jus buah tomat, sudah mengandung asam laktat. Menurut Fleming $e t$ al. (1985), bakteri asam laktat menghasilkan enzim laktat dehidrogenase yang berperan sebagai katalisator oksidasi asam laktat menjadi 
Tabel 1. Sifat-sifat isolat bakteri asam laktat dari buah tomat (Properties oflactic acid bacteria isolated from tomato fruit)

\begin{tabular}{lccc}
\hline \hline Sifat (Properties) & Isolat A (Isolate A) & Isolat B (Isolate B) & Isolat C (Isolate C) \\
\hline $\begin{array}{l}\text { Garm (Gram) } \\
\text { Bentuksel (Cel type) }\end{array}$ & Bulat (Round) & Bulat (Round) & Bulat (Round) \\
$\begin{array}{l}\text { Susunan sel } \\
\text { (Cel arrangement) }\end{array}$ & Rantai (Chain) & Rantai (Chain) & Rantai (Chain) \\
$\begin{array}{l}\text { Spora (Spore) } \\
\text { Katalase (Cataiase) }\end{array}$ & - & - & - \\
$\begin{array}{l}\text { Homofermentatif } \\
\text { (Homofermentatif) }\end{array}$ & - & - & - \\
Genus (Genus) & Streptococcus & Streptococcus & Streptococcus \\
\hline
\end{tabular}

Tabel 2. Pertumbuhan bakteri isolat A pada berbagai med ia dan kondisi

(Growth of bacteria isolate-A in some medium and condition)

\begin{tabular}{lc}
\hline \hline $\begin{array}{c}\text { Media dan kondisi pertumbuhan } \\
\text { (Media and growth condition) }\end{array}$ & $\begin{array}{c}\text { Pertumbuhan } \\
\text { (Growth) }\end{array}$ \\
\hline MRS broth, $10^{\circ} \mathrm{C}$ & Positif \\
MRS broth, $40^{\circ} \mathrm{C}$ & Positif \\
MRS broth, $45^{\circ} \mathrm{C}$ & Negatif \\
MRS broth $\mathrm{pH} 9,6$ & Negatif \\
MRS broth, $4 \% \mathrm{NaCl}$ & Positif \\
MRS broth, $6,5 \% \mathrm{NaCl}$ & Negatif \\
Susu $+0,3 \%$ metil biru & Positif \\
(Milk $+0.3 \%$ methylene blue) & Streptococcus lactis \\
Spesies (Species) &
\end{tabular}

Tabel 3 Sifat kima wi ekstrak metabolik yang dihasilkan oleh Streptococcus lactis A (Chemical properties of metabolic extract produced by Streptococcus lactis A)

\begin{tabular}{lcccc}
\hline \hline \multicolumn{1}{c}{$\begin{array}{c}\text { Sifat kimiawi } \\
\text { (Chemical properties) }\end{array}$} & \multicolumn{2}{c}{ Media (Medium) } & \multicolumn{2}{c}{$\begin{array}{c}\text { Ekstrak metbolik } \\
\text { (Metabolic extract) }\end{array}$} \\
\cline { 2 - 5 } & MRS broth & $\begin{array}{c}\text { Jus tomat } \\
\text { (Tomato } \\
\text { juice) }\end{array}$ & $\begin{array}{c}\text { MRS broth } \\
\text { Jus tomat } \\
\text { (Tomato } \\
\text { ñice) }\end{array}$ \\
\hline $\mathrm{pH}$ & 6,20 & 4,93 & 5,62 & 4,24 \\
Keasaman (\% Asam & & & & \\
$\begin{array}{l}\text { (Acidity (\% lactic acid)) } \\
\mathrm{H} 2 \mathrm{O} 2(\%)\end{array}$ & 0,07 & 0,15 & 1,55 & 2,14 \\
\hline
\end{tabular}


asam piruvat dan hidrogen peroksida.

Selama penyimpanan, pertumbuhan bakteri psikrofil pada daging segar yang telah dicelup dalam ekstrak metabolik dapat ditekan dibandingkan dengan pada kontrol (Gambar 1). Penghambatan EMT lebih besar daripada penghambatan EMM. Adanya hidrogen peroksida dalam ekstrak mampu menghambat pertumbuhan bakteri (Nickerson and Sinskey, 1972) dengan mengoksidasi gugus sulfhidril pada enzim-enzim yang berperan dalam metabolisme. Daeschel (1989) menyatakan bahwa hidrogen peroksida dapat bereaksi dengan komponen-komponen organik dalam bahan pangan menghasilkan metabolit yang dapat menghambat petumbuhan bakteri. Jumlah asam laktat yang lebih besar pada EMT juga merupakan faktor penurunan $\mathrm{pH}$ dan penghambatan pertumbuhan bakteri lebih besar daripada yang terjadi pada EMM dan kontrol. Dikemukakan oleh Darmadji (1990) bahwa asam laktat menghambat transpor nutrien ke dalam sel bakteri dan menghambat aktivitas beberapa enzim. Asam sitrat pH 4,93 ternyata tidak dapat menghambat pertumbuhan bakteri dalam daging, bahkan pertumbuhannya lebih besar daripada kontrol yang lain (daging dicelup dalam aquades steril), Beberapa bakteri psikrofil seperti Pseudomonas mampu menggunakan asam sitrat sebagai sumber karbon untuk pertumbuhannya (Buchanan and Gibbons, 1974). Penghambatan pertumbuhan bakteri kemungkinan juga disebabkan oleh adanya senyawa diasetil yang terdapat dalam ekstrak metabolik. Senyawa tersebut merupakan bakterisida yang efektif(Dubois et al., 1979; Jay, 1982; Gilliland, 1985). Menurut Kaneko et al. (1980) bakteri asam laktat dapat memproduksi diasetil dalam media MRS broth pada suhu $30^{\circ} \mathrm{C}$ selama 6-24 jam.

Selama penyimpanan, TVB daging mengalami peningkatan tetapi dapat ditekan jika daging dicelup lebih dahulu dalam ekstrak metabolik (Gambar 2). TVB merupakan hasil degradasi senyawa-senyawa nitrogen yaitu protein dan asam amino, menjadi senyawa- senyawa yang lebih sederhana seperti kadaverin, indol, skatol, ammonia, merkaptan, dan basa organik lainnya (Eskin et al., 1975; Jay, 1978; Vidal-Corou et al., 1990) yang dilakukan oleh bakteri. Kenaikan TVB ini sesuai dengan pertumbuhan bakteri selama penyimpanan di mana pada daging yang dicelup EMT lebih rendah daripada yang dicelup dalam EMM mau pun kedua kontrol.

Terdapatnya asam laktat dalam ekstrak metabolik dapat berpengaruh pada $\mathrm{pH}$ daging seperti terlihat pada Gambar 3, pH daging kontrol tampak lebih tinggi. Meski pun demikian nilai $\mathrm{pH}$ daging selama penyimpanan mengalami kenaikkan oleh karena terbentuknya TVB yang bersifat basis. Data ini juga mengindikasikan bahwa nilai $\mathrm{pH}$ yang rendah mampu menghambat pertumbuhan bakteri seperti yang terlihat pada daging yang dicelup dalam ekstrak metabolik.

Data hasil pengujian Eber menunjukkan daging yang dicelup dalam EMM dan EMT belum mengalami pembusukan meski pun telah disimpan selama 8 hari bahkan kemungkinan lebih lama lagi, sebaliknya daging kontrol telah mulai membusuk pada hari kelima penyimpanan (Tabel 4) yang ditandai dengan pembentukan kabut berwama putih. Kurniasih et al. (1989) menyatakan bahwa kabut berwarna putih timbul sebagai akibat terbentuknya ammonia yang bereaksi dengan asam klorida yang terdapat pada reagen Eber.

\section{Kesimpulan}

Kesimpulan yang dapat diperoleh dari penelitian ini adalah bahwa EMT dapat dimanfaatkan untuk mempertahankan kesegaran daging selama penyimpanan. Pada suhu rendah kesegaran daging yang diawetkan dengan EMT dapat dipertahankan sampai 8 hari, bahkan kemungkinan dapat lebih lama. Meski pun demikian masih perlu dilakukan penelitian lebih lanjut untuk mengetahui batas limit waktu simpannya. 
Tabel 4. Uji eber pada daging selama penyimpanan pada suu $5^{\circ} \mathrm{C}$

(Eber analysis for meat during storage at $5^{\circ} \mathrm{C}$ )

\begin{tabular}{|c|c|c|c|c|c|c|}
\hline \multirow{2}{*}{$\begin{array}{l}\text { Perlakuan } \\
\text { (Treatment) }\end{array}$} & \multicolumn{6}{|c|}{$\begin{array}{l}\% \text { kabut yang terbentuk pada hari penyimpanan } \\
\text { (\% fog formation at the of storage) }\end{array}$} \\
\hline & $\begin{array}{l}0 \text { hari } \\
\text { (day) }\end{array}$ & $\begin{array}{l}1 \text { hari } \\
\text { (day) }\end{array}$ & $\begin{array}{l}3 \text { hari } \\
\text { (day) }\end{array}$ & $\begin{array}{l}5 \text { hari } \\
\text { (day) }\end{array}$ & $\begin{array}{l}7 \text { hari } \\
\text { (day) }\end{array}$ & $\begin{array}{l}8 \text { hari } \\
\text { (day) }\end{array}$ \\
\hline EMM & 0 & 0 & 0 & 0 & 0 & 0 \\
\hline EMT & 0 & 0 & 0 & 0 & 0 & 0 \\
\hline Kontrol A & & & & & & \\
\hline $\begin{array}{l}\text { (Control A) } \\
\text { Kontrol B }\end{array}$ & 0 & 0 & 0 & 56 & 100 & 100 \\
\hline (Control B) & 0 & 0 & 0 & 44 & 100 & 100 \\
\hline
\end{tabular}

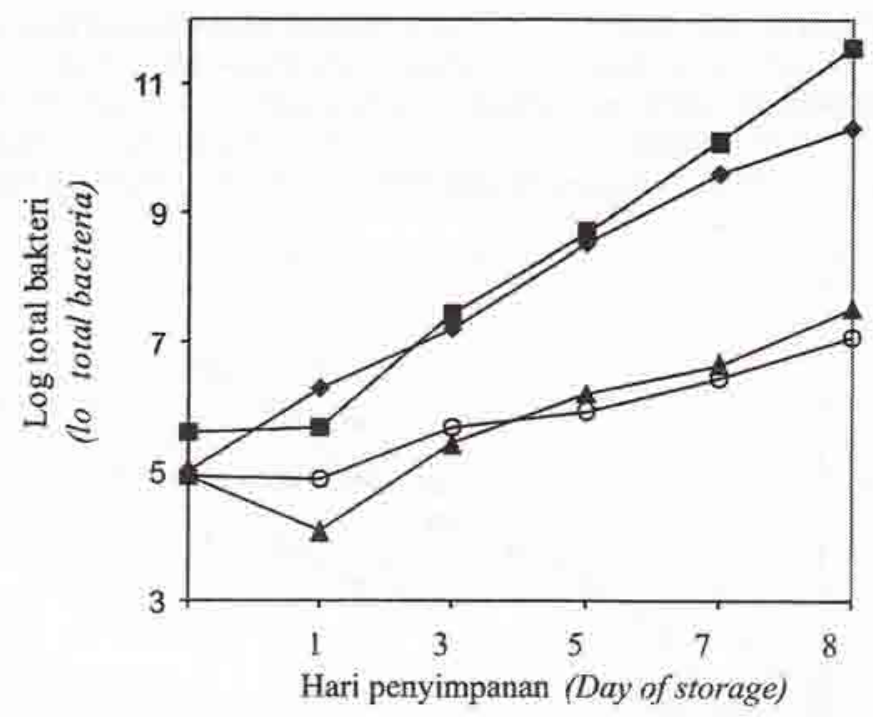

Gambar 1. Pertu mbuhan bakteri pada daging selama penyimpanan pada suhu $5^{\circ} \mathrm{C}$ (Growth of meat bacteria during storge at $5^{\circ} \mathrm{C}$ ).

daging dicelup dala maquades steril (meat diped in steril aquadest); m daging dicelup dalam

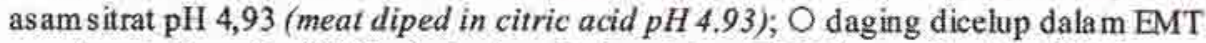
(meat dipped in EMT); $\triangle$ daging dicelup dalam EMM(meat diped in EMM). 


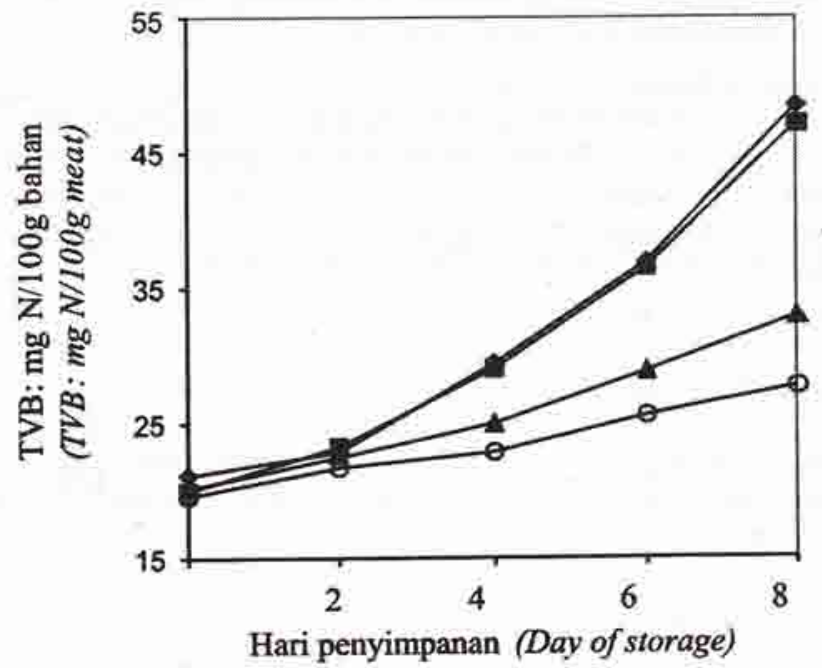

Gambar 2. Perubahan "total volatile base" (TVB) daging selama penyimpanan pada suhu $5^{\circ} \mathrm{C}$ (Change of total volatile hase (TVB) of meat during storage at $5^{\circ} \mathrm{C}$ ).

daging dicelup dalam aquades steril (meat diped in steril aquadest); : daging dicelup dalam asam sitrat $\mathrm{pH} \mathrm{4,93} \mathrm{(meat} \mathrm{diped} \mathrm{in} \mathrm{citric} \mathrm{acid} \mathrm{pH} \mathrm{4.93);} \mathrm{O}$ daging dicelup dalam EMT (meat dipped in EMT); $\triangle$ daging dicehup dalam EMM (meat diped in EMM).

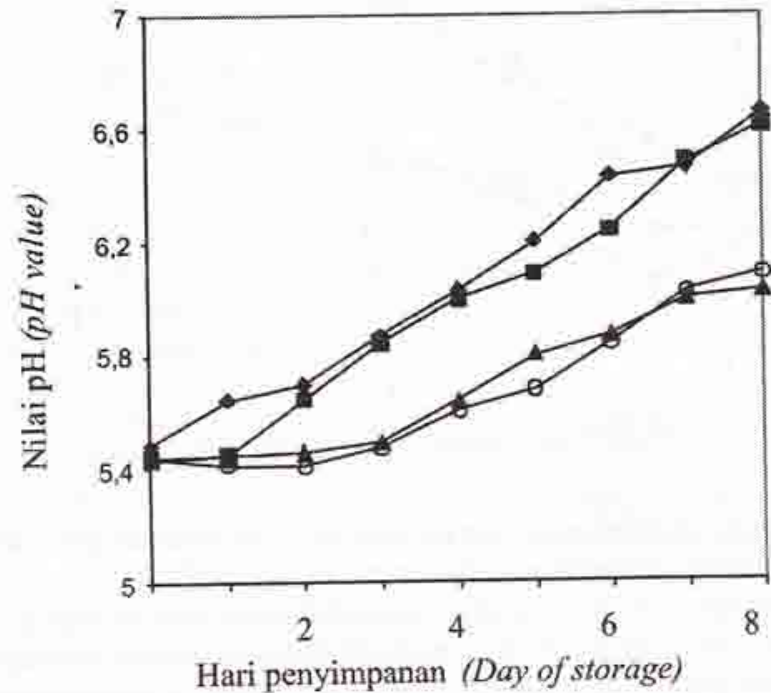

Gambar 3. Perubahan nilai $\mathrm{pH}$ daging selama penyimpanan pada sumu $5^{\circ} \mathrm{C}$. ( Change of $\mathrm{pH}$ value of meat during storage at $5^{\circ} \mathrm{C}$ ).

daging dicelup dalam aquades steril (meat diped in steril aquadest); daging dicelup dalam asam sitrat $\mathrm{pH} \mathrm{4,93} \mathrm{(meat} \mathrm{diped} \mathrm{in} \mathrm{citric} \mathrm{acid} \mathrm{pH} 4.93$ ); $\mathrm{O}$ daging dicelup dalam EMT (meat dipped in EMT); $\triangle$ daging dicelup dalam EMM(meat diped in EMM). 


\section{Daftar Pustaka}

Amad, H. A, and J. A. Marcello, 1989. Effect of Gas Atmosphere Packaging on Phsychrotrophic Growth and Succession on Steak Surface, J. Food Sci., 54 : 274 277.

Beishier, L. 1974. Microbiology in Practice : Individualized Instruction for the Allied Health Science. Canfield Press. San Fransisco.

Buchanan, R. E. and N. E. Gibbons. 1974. Bergey's Manual of Determinative Bacteriology, 8th ed., Baltimore, Wilkins, Company.

Daeschel, M. A. 1989. Antimicrobial Substance of Lactic Acid Bacteria for Use of Food Preservatives, Food Technol., 1 : 164-166.

Darmadji, P. 1990. Studies on Preservative Qualities of Fermented Dendeng Giling, Master Thesis of Graduate School of Agricuture, Okayama University.

Dubois, G., H. Beaumier, and R. Charboneau. 1979. Inhibition of Bacteria Isolated from Ground Meat by Streptococcaceae and Lactobacillaceae, J. Food Sci., 44 : 1649 1652.

Eskin, N. A. M., H. M. Henderson, and R. J. Townsend. 1975. Biochemistry of Foods. Academic Press. New York.

Fleming, H. P., R. F. M. Feeters, and M. A Daeschel. 1985. The Lactobacilli, Pediococci, and Leuconostoc: Vegetables Products, in Bacterial Starter Culture for Foods (S. E. Gilliland, Ed.). CRC Press Inc. Florida.

Gilliland, S. E. 1985. Role of Starter Culture Bacteria in Food Preservation, in Bacterial Starter Culture for Food (S.E. Gilliland, Ed.). CRC Press Inc. Florida.

Jay, J. M. 1978. Modern Food Microbiology. McGraw-Hill BookCo. New York.

Jay, J. M. 1982. Effect of Diacetyl on Foodborne Microorganisms, J. Food Sci., 47 : 1829 1831.

Jutono, J. Sudarsono, S. Hartadi, S. Kabirun, S. Darmowiyoto, dan Soesanto. 1980. Pedoman Praktikum Mikrobiologi Umum. Fakultas Pertanian UGM. Yogyakarta.
Kaneko, T., H. Suzuki, and Takahashi. 1986. Diacetyl Formation and Degradation by Streptococcus lactis subsp. Diecetylactis 3022, Agric. Biol. Chem., 50:2639-2641.

Kurniasih, Bambang S., Syariffudin T. 1989. Pemeriksaan Mutu Daging Ikan dan Udang, Laporan Penelitian. Pusat Antar Universitas Pangan dan Gizi UGM. Yogyakarta.

Nikerson, J. T. and A. J. Sinskey. 1972. Microbiology of Food and Food Processing. American Elsevier Pbl. Co. New York.

Pulusani, S. R., D. R. Rao, and G. R. Sunki. 1979. Antimicrobial Activity of Lactic Cultures : Partial Purification and Characterization of Antimicrobial Compound(s) Produced by Streptococcus thermophilus, J. Food Sci., 44: 575-578.

Reddy, S. G., R. L. Herickson, and H. J. Oison. 1970. The Influence of Lactic Culture on Ground Beef Quality, J. Food Sci., 35 : 314-318.

Reddy, S. G. and M. L. Chen. 1975. Influence of Lactic Culture on the Biochemical, Bacterial, and Organoleptic Changes in Beef, J.Food. Sci., 40: 725-728.

Sneath, P. H. A., N. S. Main, M. E. Sharpe, and J. G. Holt. 1986. Bergey's Manual Systematic Bacteriology. Vol 2. The William Wilkins Co. London.

Sudiarti, T. 1978. Pengaruh Pemakaian Tetrasiklin, Pasteurisasi, dan Kombinasinya Terhadap Kualitas Daging yang Disimpan dalam Refrigerator. Skripsi S-1, Fakultas Teknologi Pertanian Universitas Gadjah Mada, Yogyakarta.

Vidal-Corou, M. C., M. L. Izquerdo-Pulido, M. C. Martin-Morro, and Marine-Font. 1990. Histamin and Tyramin in Meat Product : Relationship with Meat Spoilage, Food. Chem., 37:239-249.

Widayaka, K. dan I. Hendratmo. 1991. Pengawetan Daging Sapi Dengan Garam dan Glukosa pada Suhu Rendah $\left(5-10^{\circ} \mathrm{C}\right)$, Dalam Kajian Kimiawi Pangan (Bambang S., Ed.), Pusat Antar Universitas Pangan dan Gizi UGM. Yogyakarta. 